\title{
PENGARUH LUAS KOLAM DAN HARGA JUAL TERHADAP PENDAPATAN USAHA PEMBESARAN IKAN NILA BLACK PRIMA
}

\section{THE INFLUENCE OF POND AREA AND SELLING PRICE ON BUSINESS INCOME TILAPIA BLACK PRIMA ENLARGEMENT}

\author{
Indri Rahmatunisa ${ }^{1 *}$, Dedi Darusman ${ }^{2}$, Riantin Hikmah Widi ${ }^{3}$ \\ ${ }^{1}$ Jurusan Agribisnis, Fakultas Pertanian, Universitas Siliwangi, Tasikmalaya \\ ${ }^{2,3}$ Dosen Jurusan Agribisnis, Fakultas Pertanian, Universitas Siliwangi, Tasikmalaya \\ *E-mail corresponding: indrirahmatunisa05@gmail.com
}

\begin{abstract}
ABSTRAK
Luas kolam merupakan permasalahan yang sangat unik terkait dengan penggunaan sumber daya yang dimiliki petani dalam proses produksi ikan nila. Harga jual ikan nila merupakan variabel yang diduga berpengaruh dalam proses keberlanjutan usaha ikan nila. Ikan nila merupakan jenis ikan konsumsi dan hidup di air tawar. Penelitian ini bertujuan untuk mengetahui pengaruh luas kolam dan harga jual terhadap pendapatan usaha pembesaran ikan nila black prima baik secara simultan maupun parsial. Metode yang digunakan pada penelitian ini yaitu metode survei. Teknik pengambilan sampel dalam penelitian ini yaitu menggunakan simple random sampling. Populasi pembudidaya ikan nila black prima di Kecamatan Sukaraja sebanyak 51 orang. Besarnya ukuran sampel yang diambil ditentukan dengan menggunakan rumus slovin, sehingga ukuran sampel dalam penelitian ini sebanyak 34 orang pembudidaya. Luas kolam dan harga jual secara simultan berpengaruh terhadap pendapatan usaha pembesaran ikan nila black prima. Sedangkan secara parsial luas kolam dan harga jual berpengaruh terhadap pendapatan usaha pembesaran ikan nila black prima.
\end{abstract}

Kata Kunci : Luas Kolam, Harga Jual, Pendapatan, Ikan Nila Black Prima

\begin{abstract}
The area of the pond is a very unique problem related to the use of resources owned by farmers in the process of tilapia production. The selling price of tilapia is a variable that is thought to have an effect in the process of sustainability of tilapia business. Tilapia is a type of fish consumption and lives in fresh water. This study aims to determine the influence of pond area and selling price on the business income of black prima tilapia enlargement both simultaneously and partially. The method used in this study is the survey method. Sampling techniques in this study are using simple random sampling. The population of black prima tilapia farmers in Sukaraja subdistrict is 51 people. The size of the sample taken was determined by using slovin formula, so that the sample size in this study as many as 34 farmers. The area of the pond and the selling price simultaneously affect the business revenue of the enlargement of black prima tilapia. While partially the area of the pond and the selling price affects the business revenue of black prima tilapia enlargement.
\end{abstract}

Keywords : Pond Area, Selling Price, Income, Black Prima Tilapia

\section{PENDAHULUAN}

Perikanan adalah semua kegiatan

yang berkaitan dengan pemanfaatan dan pengelolaan sumber daya ikan dan lingkungannya mulai dari pra produksi, produksi, pengolahan sampai dengan proses pemasaran yang dilaksanakan dalam suatu sistem bisnis perikanan (UU Nomor 45 Tahun 2009). Perikanan merupakan potensi ekonomi yang dapat 


\section{PENGARUH LUAS KOLAM DAN HARGA JUAL TERHADAP PENDAPATAN USAHA \\ PEMBESARAN IKAN NILA BLACK PRIMA \\ Indri Rahmatunisa, Dedi Darusman, Riantin Hikmah Widi}

dimanfaatkan untuk masa depan bangsa, sebagai tulang punggung pembangunan nasional.

Undang-Undang Nomor 45 Tahun 2009 menjelaskan, pemanfaatan perikanan berpengaruh terhadap peningkatan kesejahteraan, peningkatan taraf hidup nelayan, pembudidaya ikan dan petambak, meningkatkan penerimaan devisa negara, menyediakan perluasan dan kesempatan kerja, meningkatkan produktivitas, nilai tambah dan daya saing hasil perikanan serta menjamin kelestarian sumber daya ikan, lahan pembudidayaan ikan serta tata ruang.

Budidaya perikanan adalah kegiatan memproduksi biota (organisme) akuatik (air) untuk mendapatkan keuntungan. Selain budidaya perikanan, dalam sektor perikanan produksi biota akuatik dapat dilakukan melalui penangkapan atau perikanan tangkap.
Produksi dari perikanan tangkap diperoleh dengan cara memanen (berburu) biota akuatik dari alam tanpa pernah memelihara. Berbeda dengan penangkapan, produksi dari budidaya perikanan diperoleh melalui kegiatan pemeliharaan biota akuatik dalam wadah dan lingkungan terkontrol.

Berdasarkan sumber air yang digunakan untuk kegiatan produksi budidaya perikanan dikenal budidaya air tawar (freshwater culture), budidaya air payau (brackishwater culture) dan budidaya laut (mariculture) marikultur. Budidaya air tawar dilakukan dengan menggunakan sumber air dari perairan tawar, sedangkan budidaya air payau dan marikultur masing-masing menggunakan perairan payau dan laut sebagai sumber airnya.

Kabupaten Tasikmalaya merupakan salah satu sentra budidaya ikan air tawar di Propinsi Jawa-Barat.

Tabel 1. Produksi dan Nilai Produksi Budidaya Ikan Air Tawar di Kabupaten Tasikmalaya Tahun 2014-2018

\begin{tabular}{lrr}
\hline \multicolumn{1}{c}{ Jenis Ikan } & Produksi (Ton) & Nilai (Rp. 1.000) \\
\hline Mas & $19.951,57$ & $359.128 .233,44$ \\
Tawes & $3.985,12$ & $63.761 .988,06$ \\
Nila & $18.400,25$ & $220.803 .044,24$ \\
Nilem & $17.527,31$ & $262.909 .724,53$ \\
Gurame & $1.505,89$ & $52.706 .071,32$ \\
Lele & $3.359,59$ & $40.315 .097,84$ \\
Bawal & 503,17 & $7.044 .373,43$ \\
Mujair & 301,15 & $2.409 .360,00$ \\
Tambakan & $1.315,20$ & $19.728 .000,00$ \\
Udang galah & 70,23 & $3.807 .196,22$ \\
Udang vanname & $1.995,80$ & $109.769 .000,00$ \\
Bandeng & 35,82 & $537.300,00$ \\
Sepat siam & 421,15 & $4.211 .463,20$ \\
Ikan lainnya & - & - \\
\hline JUMLAH & $69.327,25$ & $1.147 .130 .852,28$ \\
\hline Tahun 2017 & $61.923,85$ & $976.333 .709,96$ \\
Tahun 2016 & $57.534,00$ & $907.454 .020,97$ \\
Tahun 2015 & $44.505,68$ & $695.101 .338,00$ \\
Tahun 2014 & $51.717,74$ & $793.849 .308,00$ \\
\hline Sumber: Dinas Perikanan Kab Tasikmalaya 2019 &
\end{tabular}


Komoditas yang sangat prospektif untuk dikembangkan meliputi ikan mas, nilem, gurame, nila dan udang galah.

Berdasarkan Tabel 1, produksi ikan air tawar di Kabupaten Tasikmalaya mengalami peningkatan dari tahun 2014 - 2018 sebesar 34\%. Peningkatan produksi ikan air tawar di Kabupaten Tasikmalaya ini didorong dengan adanya peningkatan jumlah penduduk yang signifikan, sehingga terjadinya peningkatan konsumsi terhadap ikan air tawar. Masyarakat saat ini lebih mementingkan kebutuhan gizi untuk kehidupan mereka dan ditambah dengan adanya program pemerintah dalam rangka meningkatkan konsumsi ikan secara nasional melalui Gerakan Memasyarakatkan Makan Ikan (GEMARIKAN), yang dicanangkan sejak tahun 2007. Kemudian, dilihat dari tabel dapat diketahui bahwa produksi tertinggi yakni sebanyak $19.951,57$ ton terdapat pada ikan mas kemudian diikuti oleh ikan nila sebanyak $18.400,25$ ton.

Salah satu ikan air tawar yang banyak dibudidayakan oleh masyarakat yaitu ikan nila. Karena, ikan nila mudah melakukan penyesuaian terhadap lingkungan, selain itu nilai jualnya yang tinggi sekaligus pertumbuhannya yang pesat serta waktu panen yang lebih pendek. Ditambah lagi, informasi pasar ikan nila semakin meluas hingga komoditas tersebut telah memberikan

nilai ekonomis dan peningkatan pendapatan serta membuka peluang bisnis untuk para petani atau pembudidaya (Irwandi, Redy Badrudin dan Melly Suryanty (2015)).

Kecamatan Sukaraja merupakan salah satu Kecamatan yang berpotensi dalam pertanian. Mata pencaharian penduduk Kecamatan Sukaraja dalam bidang pertanian meliputi perkebunan, peternakan dan perikanan. Perikanan di Kecamatan Sukaraja memiliki prospek yang baik untuk diusahakan, namun ada beberapa kendala yang dihadapi oleh pembudidaya yaitu sebagian besar pembudidaya masih kurang percaya diri terhadap profesi di bidang perikanan, pembudidaya masih banyak yang kekurangan dalam modal untuk memulai usaha, sebagian pembudidaya masih banyak yang skala usahanya untuk kebutuhan keluarga belum berorientasi kepada bisnis dan berbudidaya ikan masih dipandang kurang menguntungkan dan berisiko, kemudian kegiatan usaha ikan ini sebagian masih dijadikan usaha sambilan.

Selain kendala tersebut,
pembudidaya juga belum bisa
memperhatikan kualitas benih unggul,
teknis budidaya yang dilakukan masih
bersifat tradisional ditandai dengan
pemupukan yang tidak diterapkan secara
khusus, pakan yang diberikan berupa
bahan makanan yang terbuang, seperti




\section{PENGARUH LUAS KOLAM DAN HARGA JUAL TERHADAP PENDAPATAN USAHA \\ PEMBESARAN IKAN NILA BLACK PRIMA \\ Indri Rahmatunisa, Dedi Darusman, Riantin Hikmah Widi}

sisa-sisa dapur, limbah pertanian berupa dedak, bungkil kelapa, dan lain-lain, perkiraan panen tidak tentu, dan menggunakan metode pembesaran campur jenis yaitu suatu cara pembesaran ikan menggunakan lebih dari satu jenis ikan dalam tempat pemeliharaan.

Saat ini permintaan ikan nila konsumsi sangat tinggi tetapi tidak diiringi dengan peningkatan produksi yang tinggi, karena pada umumnya luas kolam yang diusahakan pembudidaya di Kecamatan Sukaraja Kabupaten Tasikmalaya masih berskala kecil sehingga hal tersebut akan mempengaruhi hasil produksi ikan nila dan pendapatan yang diterima oleh pembudidaya. Hasil produksi dan tingkat pendapatan diharapkan dapat meningkatkan kesejahteraan keluargannya. Pendapatan yang diterima pembudidaya dipengaruhi juga oleh harga jual yang diberikan pembudidaya, harga jual di tingkat pembudidaya di Kecamatan Sukaraja berbeda-beda disesuaikan dengan kesepakatan antara pembudidaya dengan tengkulak.

Pemerintah maupun perusahaan swasta selalu mencari solusi dari permasalahan yang dihadapi pembudidaya khususnya dalam penyediaan benih unggul. Salah satu perusahaan yang ikut memberikan solusi mengenai permasalahan pembudidaya adalah CP PRIMA. Perusahaan yang bergerak di bidang produksi pakan ikan ini, memunculkan jenis ikan nila baru yang di beri nama jenis ikan nila black prima. Ikan ini dapat membantu kendala yang biasanya dihadapi oleh pembudidaya seperti menyediakan benih unggul yang tahan dengan penyakit. Kemudian perusahaan tersebut tidak hanya mengeluarkan jenis ikan nila saja, tetapi perusahaan membantu pembudidaya ikan dengan memberikan suatu edukasi mengenai cara budidaya ikan yang baik melalui teknologi semi intesif.

Ikan nila black prima tentunya memiliki keunggulan. Keunggulan tersebut dirasakan oleh pembudidaya ikan karena ikan jenis nila ini dapat mempercepat pertumbuhan sehingga dapat mempercepat proses penjualan yang akhirnya berdampak dalam memperoleh pendapatan yang cepat. Pakan yang diberikan pada ikan nila ini memakai pakan khusus yang berkualitas sehingga dapat mempercepat laju pertumbuhan ikan dan bobot ikan yang sesuai. Proses budidaya ikan nila black juga tidak terlepas pada penggunaan teknologi. Penerapan teknologi budidaya semi intensif dapat membantu peroses budidaya yang optimal. 


\section{METODE PENELITIAN}

Penelitian dilaksanakan di Kecamatan Sukaraja Kabupaten Tasikmalaya. Adapun waktu penelitian dilaksanakan pada bulan Januari 2020 sampai dengan bulan Desember 2020. Metode penelitian yang digunakan adalah metode survei. Metode survei adalah suatu metode yang digunakan untuk mendapatkan data dari tempat tertentu yang alamiah (bukan buatan) dengan cara mengedarkan kuesioner, test dan wawancara terstruktur (Sugiyono, 2017). Populasi adalah wilayah generalisasi yang terdiri atas obyek/subyek yang mempunyai kualitas dan karakteristik tertentu yang ditetapkan oleh peneliti untuk dipelajari dan kemudian ditarik kesimpulannya. Populasi bukan hanya orang tetapi juga obyek dan benda-benda alam yang lain. Populasi juga bukan sekedar jumlah yang ada pada obyek/subyek yang dipelajari, tetapi meliputi seluruh karakteristik/sifat yang dimiliki oleh subyek atau obyek itu. Jadi, dalam penelitian ini populasi yang digunakan adalah seluruh kelompok pembudidaya ikan nila black prima yang ada di Kecamatan Sukaraja berjumlah 51 anggota dari 3 kelompok pembudidaya ikan.

Sampel adalah bagian dari jumlah dan karakterisktik, misalnya keterbatasan dana, tenaga dan waktu, maka peneliti dapat menggunakan sampel yang diambil dari populasi itu. Untuk pengambilan sampel penulis menggunakan metode simple random sampling yaitu teknik pengambilan sampel secara acak. Besarnya ukuran sampel yang diambil dalam penelitian ini ditentukan dengan perumusan Slovin, (Husein (2003) dalam Okrian dkk (2014)).

$$
\mathrm{n}=\frac{N}{1+N e^{2}}
$$

Keterangan :

$\mathrm{n}=$ Sampel

$\mathrm{N}=$ Ukuran Populasi

$e=$ Persentase kelonggaran ketidak telitian karena kesalahan pengambilan sampel yang masih dapat di tolerir atau diinginkan sebesar $10 \%$

Berdasarkan rumus di atas, maka data ukuran sampel pada lima kelompok pembudidaya ikan di Kecamatan Sukaraja Kabupaten Tasikmalaya, diketahui dengan hasil penelitian sebagai berikut:

$$
\begin{gathered}
\mathrm{n}=\frac{51}{1+51.0,1^{2}} \\
\mathrm{n}=\frac{51}{1+0,51} \\
\mathrm{n}=\frac{51}{1,51} \\
\mathrm{n}=33,77 \sim 34 \text { sampel }
\end{gathered}
$$

Berdasarkan rumus tersebut diperoleh jumlah sampel pembudidaya seluruhnya 34 sampel. Kemudian masing-masing sampel diproporsi ke tiaptiap kelompok pembudidaya ikan ditentukan secara proportionate simple random sampling dengan rumus :

$$
\mathrm{ni}=\frac{\mathrm{Ni}}{\mathrm{N}} \times \mathrm{n}
$$




\section{PENGARUH LUAS KOLAM DAN HARGA JUAL TERHADAP PENDAPATAN USAHA \\ PEMBESARAN IKAN NILA BLACK PRIMA \\ Indri Rahmatunisa, Dedi Darusman, Riantin Hikmah Widi}

Keterangan:

$$
\begin{array}{ll}
\mathrm{ni} & =\text { Jumlah sampel menurut kelompok } \\
\mathrm{Ni} & =\text { Jumlah populasi menurut kelompok } \\
\mathrm{N} & =\text { Jumlah populasi seluruhnya } \\
\mathrm{n} & =\text { Jumlah sampel seluruhnya }
\end{array}
$$

Hasil yang diperoleh, sebagai berikut :

1. Sampel pada Pokdakan Sinar Tanjung:

$$
\text { ni }=\frac{13}{51} \times 34=8,66 \sim 9
$$

2. Sampel pada Pokdakan Tirta Mekar:

$$
\mathrm{ni}=\frac{14}{51} \times 34=9,33 \sim 9
$$

3. Sampel pada Pokdakan Gorowong:

$$
\mathrm{ni}=\frac{24}{51} \times 34=13,35 \sim 16
$$

Dari hasil perhitungan diatas maka diperoleh jumlah sampel pembudidaya dari tiga pokdakan yaitu Pokdakan Sinar Tanjung sebanyak 9 sampel, Pokdakan Tirta Mekar sebanyak 9 sampel, dan Pokdakan Gorowong sebanyak 16 sampel.

\section{Kerangka Analisis}

\section{Analisis Pendapatan}

Analisis pendapatan dalam usaha pembesaran ikan nila black prima digunakan persamaan sebagai berikut :

a. Pendapatan $=$ Penerimaan - Biaya Total

b. $\quad$ Penerimaan $=$ Py.Y dimana Py adalah Harga Produksi (Rp/kg) dan $Y$ adalah Jumlah Produksi (kg).

b. Biaya Total $=$ Biaya Tetap + Biaya Variabel

\section{Uji Asumsi Klasik}

a. Uji Normalitas

Uji normalitas digunakan untuk mengetahui apakah sebuah data dalam penelitian telah memiliki distribusi secara normal atau tidak, sebuah data akan terlihat baik digunakan untuk menganalisis dalam menjawab dan menjelaskan fenomena apabila data penelitian memiliki distribusi secara normal atau memenuhi normalitas data.

b. Uji Multikolinearitas

Uji multikolinearitas bertujuan untuk mendeteksi apakah variabel independen pada model regresi saling berkorelasi. Untuk memenuhi kriteria BLUE (Best, Linier, Unbeased, Estimated), tidak boleh terdapat korelasi antara setiap variabel independen pada model regresi. Apabila terjadi korelasi antara variabel independen, maka variabel tersebut dapat dikatakan tidak orthogonal. Salah satu cara untuk mendeteksi gejala multikolinearitas adalah dengan melihat nilai tolerance value dan Variance Inflastion Factor (VIF) dengan kriteria keputusan sebagai berikut:

1. Apabila tolerance value $>0,1$ dan VIF $<10$, maka dapat disimpulkan tidak terjadi gelaja multikolinearitas antar variabel independen pada model regresi.

2. Apabila tolerance value $<0,1$ dan VIF $>10$, maka dapat disimpulkan terjadi 
gelaja multikolinearitas antar variabel independen pada model regresi.

c. Uji Heteroskedastisitas

Heteroskedastisitas bertujuan untuk mengetahui apakah dalam model regresi terjadi ketidaksamaan variance dari residual satu pengamatan ke pengamatan lain. Model regresi yang baik harus memiliki variance yang sama (homoskedastisitas). Ada beberapa cara untuk mendeteksi ada tidaknya hererokedatisitas, yaitu dengan melihat scatterplot serta melalui/menggunakan uji gletjer, uji Park, dan uji White.

1. Jika pada grafik scatter plot terlihat titik-titik yang membentuk pola tertentu, yang teratur (misal bergelombang, melebar kemudian menyempit), maka dapat disimpulkan telah terjadi masalah Heteroskedastisitas.

2. Jika pada grafik scatter plot, titik-titik menyebar di atas dan di bawah angka nol pada sumbu $Y$ serta tidak membentuk pola tertentu yang teratur (misal bergelombang, melebar kemudian menyempit), maka dapat disimpulkan tidak terjadi masalah heteroskedastisitas (variance sama/Homoskedastisitas).

d. Uji Autokorelasi

Uji Autokorelasi digunakan untuk mendeteksi apakah terjadi korelasi antara residu pada periode saat ini ( $t$ ) dengan residu pada periode satu periode sebelumnya (t-1). Untuk memenuhi kriteria BLUE (Best, Linier, Unbeased, Estimated), model regresi harus terbebas dari gejala autokorelasi. Untuk mendeteksi gejala autokorelasi dapat menggunakan uji statistik yaitu uji DurbinWatson dengan kriteria pengambilan keputusan sebagai berikut :

1. Apabila $d w<d l$, maka terjadi autokorelasi negatif

2. Apabila $\mathrm{dl}<\mathrm{dw}<\mathrm{du}$, maka tidak dapat disimpulkan

3. Apabila $d u<d w<4-d u$, maka tidak terjadi autokorelasi negatif dan positif

4. Apabila 4-du $>d w<4-d u$, maka tidak dapat disimpulkan

\section{Koefisien determinasi $\left(\mathbf{R}^{2}\right)$}

Koefisien determinasi $\left(\mathrm{R}^{2}\right)$, yaitu suatu nilai yang menggambarkan seberapa besar perubahan atau variasi dari variabel dependen bisa dijelaskan oleh perubahan atau variasi dari variabel independen. Jika $\mathrm{R}^{2}$ (bisa juga ditampilkan dalam \%) semakin dekat dengan 1 (atau 100\%), maka model regresi tersebut cukup baik untuk digunakan, sedangkan bila $\mathrm{R}^{2}$ semakin dekat dengan 0 (atau 0\%), maka model regresi tersebut tidak cukup baik untuk digunakan.

\section{Analisis Regresi Linier Berganda}

Pengaruh luas kolam dan harga jual terhadap pendapatan usaha pembesaran Ikan Nila Black Prima di Kecamatan Sukaraja Kabupaten 


\section{PENGARUH LUAS KOLAM DAN HARGA JUAL TERHADAP PENDAPATAN USAHA \\ PEMBESARAN IKAN NILA BLACK PRIMA \\ Indri Rahmatunisa, Dedi Darusman, Riantin Hikmah Widi}

Tasikmalaya digunakan rumus sebagai berikut (Dyah, 2012).

$$
Y=a+b_{1} X_{1}+b_{2} X_{2}+e
$$

dimana :

$\mathrm{Y}=$ Pendapatan Usaha Pembesaran Ikan Nila Black Prima

$\mathrm{a} \quad=$ Konstanta

$\mathrm{X}_{1} \quad=$ Luas Kolam

$\mathrm{X}_{2}$ = Harga Jual

$\mathrm{b}_{1}, \mathrm{~b}_{2} \quad=$ Koefisien Regresi

e = Standar Error

\section{Uji Simlutan (Uji F)}

Uji $F$ dilakukan untuk melihat seberapa besar pengaruh variabel independen secara bersama-sama terhadap variabel dependen. Uji F dalam menggunakan SPSS dapat diperoleh melalui uji ANOVA.

Hipotesis :

$\mathrm{H}_{0}:$ bi $=0(\alpha=5 \%)$, artinya secara bersamasama (simultan) luas kolam dan harga jual tidak ada pengaruh secara nyata terhadap pendapatan.

$\mathrm{Hi}:$ bi $\neq 0$ ( $\alpha=5 \%)$, artinya secara bersamasama (simultan) luas kolam dan harga jual ada pengaruh secara nyata terhadap pendapatan.

Kriteria pengambilan keputusan :

1. $F_{\text {hitung }}<F_{\text {tabel }}(\alpha=5 \%)$ atau nilai sig $>$ $\alpha, \mathrm{H}_{0}$ diterima berarti secara bersamasama (simultan) variabel independen berpengaruh tidak nyata terhadap variabel dependen.

2. $\mathrm{F}_{\text {hitung }}>\mathrm{F}_{\text {tabel }}(\alpha=5 \%)$ atau nilai sig < $\alpha, \mathrm{H}_{0}$ ditolak berarti secara bersamasama (simlutan) variabel independen berpengaruh secara nyata terhadap variabel dependen.

\section{Uji Parsial (Uji t)}

Uji t merupakan uji yang dilakukan secara masing-masing atau satu variabel independen terhadap variabel dependen. Hipotesis :

$\mathrm{H}_{0}:$ bi $=0(\alpha=5 \%)$, artinya koefisien regresi dari masing-masing variabel luas kolam dan harga jual berpengaruh tidak nyata terhadap variabel pendapatan.

$\mathrm{Hi}:$ bi $\neq 0$, artinya koefisien regresi dari masing-masing variabel luas kolam dan harga jual berpengaruh nyata terhadap variabel pendapatan.

Kriteria pengambilan keputusan :

1. $t_{\text {hitung }} \leq t_{\text {tabel }}(\alpha=5 \%)$ atau nilai sig $>$ $\alpha, \mathrm{H}_{0}$ diterima berarti koefisien regresi dari variabel independen berpengaruh tidak nyata terhadap variabel dependen.

2. $t_{\text {hitung }}>t_{\text {tabel }}(\alpha=5 \%)$ atau nilai sig $<$ $\alpha, \mathrm{H}_{0}$ ditolak berarti koefisien regresi dari variabel independen berpengaruh secara nyata terhadap variabel dependen.

\section{HASIL DAN PEMBAHASAN}

\section{Pendapatan Usaha Pembesaran Ikan}

\section{Nila Black Prima}

Pendapatan usaha pembesaran ikan nila black prima adalah selisih antara penerimaan dengan biaya total. Hasil analisis untuk pendapatan usaha pembesaran ikan nila black prima dapat dilihat pada Tabel 2. 
Tabel 2. Jumlah Responden Berdasarkan Pendapatan Usaha Pembesaran Ikan Nila Black Prima Setiap Kali Panen / 3 bulan.

\begin{tabular}{lcc}
\hline \multicolumn{1}{c}{ Pendapatan Usaha Pembesaran Ikan Nila / 3 bulan } & $\begin{array}{c}\text { Jumlah } \\
\text { (orang) }\end{array}$ & Persentase (\%) \\
\hline Rp 332.550 - Rp 2.549.799 & 28 & 82,35 \\
Rp 2.549.800 - Rp 4.767.049 & 4 & 11,77 \\
Rp 4.767.050 - Rp 6.984.300 & 1 & 2,94 \\
Rp 6.984.301 - Rp 13.968.601 & 1 & 2,94 \\
\hline Jumlah & 34 & 100 \\
\hline Mean & 1.949 .350 & \\
\hline Minimun & 332.550 & \\
\hline Maximum & 13.636 .050 & \\
\hline
\end{tabular}

Tabel 2. menunjukkan bahwa responden terbanyak adalah yang berpendapatan berkisar Rp 332.550 - Rp 2.549.799 yaitu sebanyak 28 orang atau $82,35 \%$ dan yang paling sedikit adalah responden yang berpendapatan antara Rp 4.767.050 - Rp 6.984.300 sebanyak 1 orang dan Rp 6.984.301 - Rp 13.968.601 sebanyak 1 orang. Rata-rata pendapatan usaha pembesaran ikan nila black prima dalam satu kali proses produksi yaitu Rp 1.949.350 dengan rata-rata luas kolam $264 \mathrm{~m}^{3}$.

Pendapatan usaha pembesaran ikan nila black prima di Kecamatan Sukaraja dalam satu kali panen yang paling rendah sebesar Rp 332.550 dan pendapatan tertinggi sebesar Rp 13.636.050. Pendapatan yang rendah tersebut dikarenakan responden memiliki luas kolam yang sempit dan usaha pembesaran ikan nila black prima hanya dijadikan usaha sambilan responden. Sedangkan pendapatan yang tinggi, responden memiliki luas kolam yang besar dan usaha tersebut dijadikan usaha utama responden.

\section{Luas Kolam Usaha Pembesaran Ikan Nila Black Prima}

Responden dalam penelitian ini mempunyai luas kolam yang berbedabeda mulai dari $60 \mathrm{~m}^{2}$ sampai dengan $2.160 \mathrm{~m}^{2}$ dengan kedalaman 1 meter. Kolam yang digunakan responden yaitu kolam yang dibuat dari kolam tanah dengan memanfaatkan sumber air dengan air tenang. Menurut Siska (2016) semakin luas kolam yang diusahakan maka akan semakin besar pula pendapatan yang diperoleh pembudidaya, hal ini dikarenakan benih ikan yang dimasukkan kedalam kolam tergantung pada luas kolam pembudidaya tersebut. Apabila luas kolam besar maka benih ikan yang dimasukkan dalam jumlah yang banyak sebaliknya apabila luas kolam pembudidaya kecil benih ikan yang dimasukkan kedalam kolam dalam jumlah sedikit.

Hasil olah data pendapatan, dalam satu kali proses produksi menunjukkan bahwa responden yang mempunyai luas kolam terkecil yaitu 


\section{PENGARUH LUAS KOLAM DAN HARGA JUAL TERHADAP PENDAPATAN USAHA \\ PEMBESARAN IKAN NILA BLACK PRIMA \\ Indri Rahmatunisa, Dedi Darusman, Riantin Hikmah Widi}

$60 \mathrm{~m}^{3}$ milik Bapak Cecep memperoleh pendapatan sebesar Rp 332.550, sedangkan luas kolam terbesar yaitu $2.160 \mathrm{~m}^{3}$ milik Ibu Yeni memperoleh pendapatan sebesar Rp 13.636.050.

\section{Harga jual Ikan Nila Black Prima}

Harga jual ikan nila black prima adalah sejumlah uang yang dibayarkan tengkulak pada saat membeli ikan nila black prima di produsen. Harga jual ikan nila black prima konsumsi yang diberikan oleh responden memiliki harga yang beragam. Kelompok Sinar Tanjung menjual ke rumah makan dengan harga borongan Rp 22.000/kg. Kelompok Gorowong menjual hasil produksi ke tim penangkap dengan harga borongan $\mathrm{Rp} 23.000 / \mathrm{kg}$, team penangkap tersebut merupakan anggota kelompok Gorowong yang mempunyai keahlian yang baik dalam penanganan ikan, agar ikan tersebut masih dalam keadaan baik ketika dijual ke pasar. Kemudian, kelompok Tirta Mekar menjual hasil produksi dengan harga borongan $\mathrm{Rp} 25.000 / \mathrm{kg} \mathrm{ke}$ tengkulak. Menurut Markisman dkk (2019), tinggi rendahnya harga jual dari penawaran hasil produksi ikan nila ditingkat pembudidaya akan mempengaruhi pendapatan yang diperoleh pembudidaya ikan nila, sehingga harga jual ditingkat pembudidaya mempengaruhi kegiatan usaha pembudidayaan ikan nila yang ditekuni baik sebagai sumber mata pencaharian utama keluarga maupun tambahan.

\section{Analisis Regresi Linier Berganda}

Untuk menganalisis luas kolam dan harga jual terhadap pendapatan usaha pembesaran ikan nila black prima digunakan analisis regresi linier berganda. Namun di dalam analisis linier berganda sangat diperlukan uji asumsi klasik dengan maksud apakah data penelitian yang digunakan telah memenuhi syarat BLUE (Best, Linier, Unbeased, Estimated).

Koefisien determinasi $\left(\mathrm{R}^{2}\right)$ adalah suatu nilai yang menunjukkan seberapa besar variasi dalam variabel terikat $(\mathrm{Y})$ dapat dijelaskan oleh variabel bebas $\left(\mathrm{X}_{\mathrm{i}}\right)$ secara bersama-sama. Berdasarkan Model Summary, diperoleh nilai $\mathrm{R}^{2}$ (RSquare) adalah 0,978. Dengan demikian, sebesar 97,8 persen variasi perubahanperubahan dalam pendapatan usaha pembesaran ikan nila black prima dapat dijelaskan oleh luas kolam $\left(\mathrm{X}_{1}\right)$ dan harga jual $\left(X_{2}\right)$. Sisanya sebesar 2,2 persen dijelaskan oleh variabel lain yang tidak dimasukkan dalam persamaan ini.

Uji $F$ dilakukan untuk melihat seberapa besar pengaruh variabel independen secara bersama-sama terhadap variabel dependen. Analisa ini dilakukan dengan membandingkan nilai sig- $\mathrm{F}$ hitung dengan $\alpha=5$ persen $(0,05)$. Berdasarkan tabel ANOVA pada Lampiran 7. nilai sig-F lebih kecil dari $\alpha$ 
$(0,00<0,05)$, artinya terima $\mathrm{H}_{1}$ dan tolak $\mathrm{H}_{0}$. Maka dapat disimpulakan bahwa secara bersama-sama (simultan) luas kolam $\left(\mathrm{X}_{1}\right)$ dan harga jual $\left(\mathrm{X}_{2}\right)$ berpengaruh terhadap pendapatan usaha pembesaran ikan nila black prima.

Hasil analisis regresi linier dan harga jual terhadap pendapatan usaha pembesaran ikan nila black prima dengan variabel bebas luas kolam $\left(\mathrm{X}_{1}\right)$ dan harga jual $\left(\mathrm{X}_{2}\right)$. Setelah dilakukan estimasi (Tabel 3) persamaan regresi dapat ditulis sebagai berikut :

$$
Y=-3073000+6223,020 X_{1}+145,228 X_{2}
$$

berganda tentang pengaruh luas kolam

Tabel 3. Hasil Pengaruh Luas Kolam dan Harga Jual Terhadap Pendapatan Usaha Pembesaran Ikan Nila Black Prima.

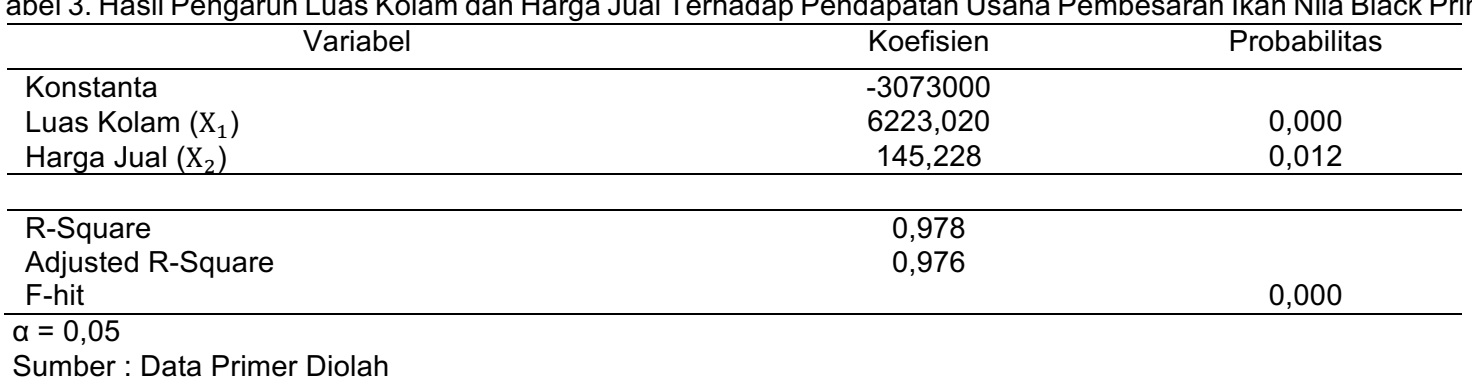

Uji t merupakan uji yang dilakukan secara masing-masing atau satu variabel independen terhadap variabel dependen. Analisa ini dilakukan dengan membandingkan antara nilai sig masingmasing variabel $\alpha=5$ persen $(0,05)$, jika nilai sig-nya lebih kecil dari $\alpha=5$ persen $(0,05)$ maka variabel independen secara parsial berpengaruh terhadap variabel dependen.

Pengaruh luas kolam terhadap pendapatan usaha pembesaran ikan nila black prima memiliki nilai signifikansi sebesar 0,00 lebih kecil dari a 5 persen $(0,000<0,05)$, maka keputusannya terima $\mathrm{H}_{1}$ dan tolak $\mathrm{H}_{0}$, artinya luas kolam berpengaruh terhadap pendapatan usaha pembesaran ikan nila black prima. Koefisien regresi didapat 6223,020 artinya setiap penambahan luas kolam 1 $\mathrm{m}^{3}$ maka pendapatan akan meningkat sebesar Rp 6.223.020. Luas kolam yang dimiliki pembudidaya ikan nila black prima di Kecamatan Sukaraja Kabupaten Tasikmalaya berbeda-beda, tetapi padat penebaran yang diterapkan seragam yaitu $8 \mathrm{ekor} / \mathrm{m}^{3}$ sehingga semakin besar luas kolam yang diusahakan maka semakin tinggi hasil produksi yang diperoleh. Hal tersebut dapat berpengaruh terhadap tinggi rendahnya pendapatan yang diperoleh pembudidaya dari usaha pembesaran ikan nila black prima.

Hasil penelitian ini sejalan dengan hasil penelitian Siska Julisa (2016) bahwa luas kolam berpengaruh terhadap pendapatan petani ikan air tawar di Nagari Taruang-Taruang Kecamatan Rao Kabupaten Pasaman. Hal ini berarti semakin luas kolam maka akan mendorong meningkatnya pendapatan 


\section{PENGARUH LUAS KOLAM DAN HARGA JUAL TERHADAP PENDAPATAN USAHA \\ PEMBESARAN IKAN NILA BLACK PRIMA \\ Indri Rahmatunisa, Dedi Darusman, Riantin Hikmah Widi}

petani ikan air tawar, sebaliknya semakin sempit luas kolam maka semakin tidak efisien petani dalam menjalankan usahanya.

Pengaruh harga jual terhadap pendapatan usaha pembesaran ikan nila black prima memiliki nilai signifikansi sebesar 0,012 lebih kecil dari a 5 persen $(0,012<0,05)$, maka keputusannya terima $\mathrm{H}_{1}$ dan tolak $\mathrm{H}_{0}$, artinya harga jual berpengaruh terhadap pendapatan usaha pembesaran ikan nila black prima. Koefisien regresi didapat 145,228 artinya setiap penambahan harga jual sebesar Rp 1.000 maka pendapatan akan meningkat sebesar Rp 145.228. Harga jual ditingkat pembudidaya memiliki harga yang berbeda-beda dari harga Rp 22.000 , Rp 23.000 dan Rp 25.000. Hal ini dapat berpengaruh terhadap tinggi rendahnya pendapatan yang diperoleh pembudidaya dari usaha pembesaran ikan nila black prima.

Penelitian ini sejalan dengan hasil penelitian Markisman dkk (2016) bahwa faktor ekonomi yang berhubungan dengan harga jual mempengaruhi pendapatan pembudidaya. Tinggi rendahnya harga jual dari penawaran hasil produksi ikan ditingkat pembudidaya akan mempengaruhi pendapatan yang diperoleh pembudidaya sehingga harga jual di tingkat pembudidaya akan mempengaruhi kegiatan usaha pembudidaya yang ditekuni baik sebagai sumber mata pencaharian utama keluarga maupun tambahan.

\section{KESIMPULAN}

Berdasarkan hasil analisis secara simultan luas kolam dan harga jual berpengaruh terhadap pendapatan usaha pembesaran ikan nila black prima. Secara parsial luas kolam dan harga jual berpengaruh terhadap pendapatan usaha pembesaran ikan nila black prima. Sedangkan pendapatan usaha pembesaran ikan nila black prima di Kecamatan Sukaraja Kabupaten Tasikmalaya sebagian besar berpendapatan berkisar antara $R p$ 332.550 - $\operatorname{Rp~2.549.799.~Rata-rata}$ pendapatan usaha pembesaran ikan nila black prima di Kecamatan Sukaraja Kabupaten Tasikmalaya yaitu $R p$ 1.949.350 dalam satu kali proses produksi dengan rata-rata luas kolam 264 $\mathrm{m}^{3}$.

\section{DAFTAR PUSTAKA}

Abd Rahman, Hj. Suprapti Supardi, dan Diah Retno Dwi Hastuti. 2005. Model Analisis Ekonomika Pertanian. Badan Penerbit Universitas Negeri Makassar. Makassar.

Amelia Dwi Nugrahaini, Suprapti Supardi dan Isti Khomah. 2018. Faktor sosial ekonomi yang mempengaruhi pendapatan pembenihan ikan nila merah di KPI Mino Ngremboko. Agrista. 6(2) : 1 11. 
Badan Pusat Statistik Kabupaten Tasikmalaya. 2019. Kecamatan Sukaraja dalam Angka 2019. Badan Pusat Statistik. Kabupaten Tasikmalaya.

Dian Susanti, Nurul H. Listiana dan Tri Widayat. 2016. Pengaruh umur petani, tingkat pendidikan dan luas lahan terhadap hasil produksi tanaman sembung. 9(2) : $75-82$.

Dinas Perikanan dan Kelautan Kabupaten Tasikmalaya. 2019.

Dyah Nirmala Arum Janie, S.E., M.Si. 2012. Statistika Deskriptif \& Regresi Linier Berganda dengan SPSS. Semarang University Press, Semarang.

Dr. R. Rina Novianty Ariawaty, SE., MS dan Siti NoNI Evita, SE., MS. 2018. Metode Kuantitatif Praktis. PT. Bima Pratama Sejahtera, Bandung.

Hasman Hasyim. 2006. Analisis hubungan karakteristik petani kopi terhadap pendapatan (Studi kasus : Desa Dolok Saribu Kecamatan Paguran Kabupaten Tapanuli Utara). Jurnal Komunikasi Penelitian. 18 (1) : 22 - 27.

Helny Melynda Astriani Meroekh, Petrus E. De Rozari, dan Christen C.Foenay. 2018. Perhitungan harga pokok produksi dalam menentukan harga jual melalui metode cost plus pricing (studi kasus pada pabrik tahu pink jaya oebufu di Kupang). Journal of Management (SME's). 7(2) : 181-2015.

H Khairuman dan Khairul Amri. 2013. Budi Daya Ikan Nila. Agro Media Pustaka, Jakarta.

Irwandi, Redy Badrudin, dan Melly Suryanty. $2015 . \quad$ Analisis pendapatan dan efisiensi usaha pembesaran ikan nila (Oreochromis Niloticus) di Desa Mekar Mulya Kecamatan Penarik Kabupaten
Mukomuko. Agrisep. 15(2) : 237253.

Ken Suratiyah. 2015. Ilmu Usahatani. Penebar Swadaya, Jakarta.

Markisman, Anhulaila M. Palampanga, dan Muhtar Lutfi. 2016. Pengaruh faktor sosial dan ekonomi terhadap pendapatan pembudidaya ikan mas di Kecamatan Dolo Selatan. EJurnal Katalogis. 4(3) : 58-69.

Masiah Mahubessy, August E. Pattiselanno dan Izaac T.Matitaputty. 2020. Analisis faktorfaktor yang mempengaruhi pendapatan petani sayur di Desa Waiheu Kecamatan Teluk Ambon Baguala. Agrilan: Jurnal Agribisnis Kepulauan. 8(1) : 26-39.

M. Ghufran H Kordi. 2010. Budi Daya Ikan Nila di Kolam Terpal. Andi, Yogyakarta.

M. Saipal, Muchtar Surullah, dan Sri Wahyuni Mustafa. 2019. Faktorfaktor yang mempengaruhi pendapatan petani tambak ikan bandeng di Desa Salekoe Kecamatan Malangke Kabupaten Luwu Utara. Jurnal Ekonomi Pembangunan. 5(1) : 31-41.

Okrian Weri Putra, Hj. Nursiah Chalid dan Nobel Aqualdo. 2014. Analisis faktor-faktor yang mempengaruhi produksi budidaya ikan nila di Kecamatan Singingi Kabupaten Kuantan Singingi. JOM FEKON. 1 : 1-16.

Priyono. 2016. Metode Penelitian Kuantitatif. Zifatama Publishing, Sidoarjo.

Republik Indonesia. 2009. UndangUndang Nomor 45 Tahun 2009 Tentang Perubahan Atas UndangUndang Nomor 31 Tahun 2004 Tentang Perikanan. Republika Indonesia, Jakarta. 
Rukmana, H. Rahmat, dan H. Herdi Yudirachman. Sukses Budi Daya Ikan Nila Secara Intensif. Lily publisher, Yogyakarta.

Siska Julisa, Lovelly Dwinda Dahen, dan Syailendra Eka Saputra. 2016. Pengaruh modal, luas kolam, dan pengalaman terhadap pendapatan petani ikan air tawar di Nagari Taruang-Taruang Kecamatan Rao Kabupaten Pasaman.

Sriyoto, Reswita, dan Hardianto. 2015. Analisis distribusi pendapatan pada usaha ikan nila di Kecamatan
Seginim Kabupaten Bengkulu

Selatan. Agrisep. 15(2) : 159-166.

Sugiyono. 2017. Metode Penelitian Kuantitatif, Kualitatif, dan R\&D. Alfabeta, Bandung.

Suhendri. Buku Pedoman Teknis Budidaya Ikan Nila.

Tegar Winasis. 2015. Untung Menggiurkan 21 Hari Sukses Pembibitan Lele, Gurami, Nila. Araska, Yogyakarta

Tim Mitra Agro Sejati. 2017. Budi Daya Ikan Nila. CV Pustaka Bengawan. 